\title{
Creating a low-carbon campus in Chaoyang University of Technology (CYUT)
}

\author{
Tao-Ming Cheng ${ }^{1}$, Hwa-Nan Chang $^{2}$, Clive Yen ${ }^{3, *}$, Ming-Hsiung Chen ${ }^{4}$ \\ ${ }^{1}$ President, Chaoyang University of Technology, 168, Jifeng E. Rd., Wufeng District, Taichung, 41349 Taiwan, R.O.C. \\ ${ }^{2}$ Assistant professor, Department of Golden-Ager Industry Management, 168, Jifeng E. Rd., Wufeng District, Taichung, 41349 \\ Taiwan, R.O.C. \\ ${ }^{3}$ Postdoctoral Researcher, Department of Environmental Engineering and Management Innovative Center of Sludge Recovery, 168, \\ Jifeng E. Rd., Wufeng District, Taichung, 41349 Taiwan, R.O.C. \\ ${ }^{4}$ Director of Officer for Environmental Safety and Health, 168, Jifeng E. Rd., Wufeng District, Taichung, 41349 Taiwan, R.O.C.
}

\begin{abstract}
Founded in 1994, the campus of Chaoyang University of Technology (CYUT) is located in the suburban area of Taichung, Taiwan. In 2009, the president of CYUT signed the Talloires Declaration to show his commitment for promoting environmental sustainability on campus. In 2012, CYUT and many other universities in Taiwan cofounded the Green University Union of Taiwan (GUUT) to collaboratively promote the concept of environmental sustainability. Following the announcement of the Sustainable Development Goals (SDGs) set by the United Nations in 2015, CYUT has been putting a lot of effort into converting itself into a green university. Four different fields of management, which are energy and resources management, accident prevention and rescue management, occupational safety and health management, and environmental management, have been promoted in the campus of CYUT for this cause. Furthermore, four management practices including implementing management systems, organizing green courses, promoting green activities and creating green environment, have been applied to improve the effectiveness of the campus management. In the case of energy and resources management in particular, not only ISO 50001 and 14001 management systems were implemented but also an intelligent energy network (iEN) was established for maintaining effective usage of the campus energy. For years of striving in creating a green university, CYUT had several remarkable accomplishments. The green open space ratio in campus is $94.43 \%$. Water-saving equipment was installed in the whole campus and reclaimed water is collected for urban reuse. Garbage reduction and classification have been enforced to make ease for later treatments. For issues related to energy and climate change, strategies, such as renewal of high energy consuming facilities, installation of green roofs, utilization of recycle energy and education of staffs were enacted and the consumed energy in campus gradually decreased in recent years. For example, the electricity and oil (including gasoline and diesel) consumption in campus of 2017 were $7.59 \%$ and $14 \%$ lower than those of 2016, respectively. In order to overcome the challenges from climate change, CYUT will continue on its process of creating a low-carbon campus focusing on energy sustainability.
\end{abstract}

\section{Introduction}

Since the Industrial Revolution, fossil fuel has been greatly used by humans which resulted in huge amount of greenhouse gas emissions. From 1880, the global average surface temperature has increased by about 0.85 ${ }^{\circ} \mathrm{C}$ [1]. To date, the Intergovernmental Panel on Climate Change (IPCC) from the United Nations (UN) has published 5 assessment reports. In their 5 th assessment report published in 2013, the term used to indicate the likelihood of an outcome between human activities and global warming was "extremely likely". It was upgraded from "very likely" which was stated in the 4th assessment report published in 2007. In other words, $95 \%$ of global warming is related to the outcomes of human activities. According to the IPCC report, the global average surface temperature could increase $0.3 \sim$ $4.8^{\circ} \mathrm{C}$ from the years of 2081 to 2100 . During that time, the crisis of global ecosystem collapse could unfold and human survival would probably be severely challenged. As for Taiwan, due to environmental pollution and highly urbanization, the phenomenon of urban heat island was formed. Therefore, during 1911 to 2009, the mean annual temperature of Taiwan has increased $1.4^{\circ} \mathrm{C}$, that is $0.14^{\circ} \mathrm{C}$ for the rate of temperature increase of every 10 years [2]. Also, the rate of the increasing amount of greenhouse gas emissions in Taiwan is nearly the highest of the whole world. Furthermore, since Taiwan is located on the western Pacific typhoon basin, the Climate Risk Index ranked Taiwan as one of the ten countries who suffers most from extreme weather events.

According to the Paris Agreement, which was negotiated in the 2015 United Nations Climate Change Conference (COP 21) held in Paris, the global temperature rise for this century is aimed to be kept under $2^{\circ} \mathrm{C}$ and even further to $1.5^{\circ} \mathrm{C}$ by pursuing with great efforts. But from the current circumstances, it

\footnotetext{
Corresponding author: pres@,cyut.edu.tw
} 
would be an uphill battle to achieve the goal. From 2006, the annual Global Risks Report published by the World Economic Forum enlisted climate change as one of the top 10 global risks. Therefore, the extreme weather events that were accompanied by climate change, such as Hurricanes Katrina and Sandy in US and Typhoon Morakot in Taiwan, have created a great survival crisis for human beings. In order to face the challenge of climate change, universities should take more social responsibility.

\section{About CYUT}

Chaoyang University of Technology (CYUT) was newly founded in 1994. Currently, CYUT comprises 5 colleges including management, science and engineering, design, humanities and social sciences, and informatics. Within the colleges, there are 22 departments (e.g., finance and business administration) that offer 22 master's programs (e.g., environmental engineering and management) and 5 doctoral programs (e.g., architecture and urban design). The currently enrolled students are about 16,000, and the faculty and staff members are over 600. CYUT is situated on the hills in the southeastern part of Taichung, Taiwan (Figure 1). The total campus area is 66.4 hectares and is divided into two campus locations according to the development time (Figure 2). Campus I is the main campus for student activities and the carbon footprint and greenhouse gas emissions in this area could be lowered. Campus II is located to the southeast of Campus I with a distance of $3 \mathrm{~km}$. It has an area of 39 hectares which is currently covered with trees and its carbon sequestration is about 291 metric tonnes $\mathrm{CO}_{2} \mathrm{e}$ per year. At present, the green open space ratio in campus is $94.43 \%$ [3].

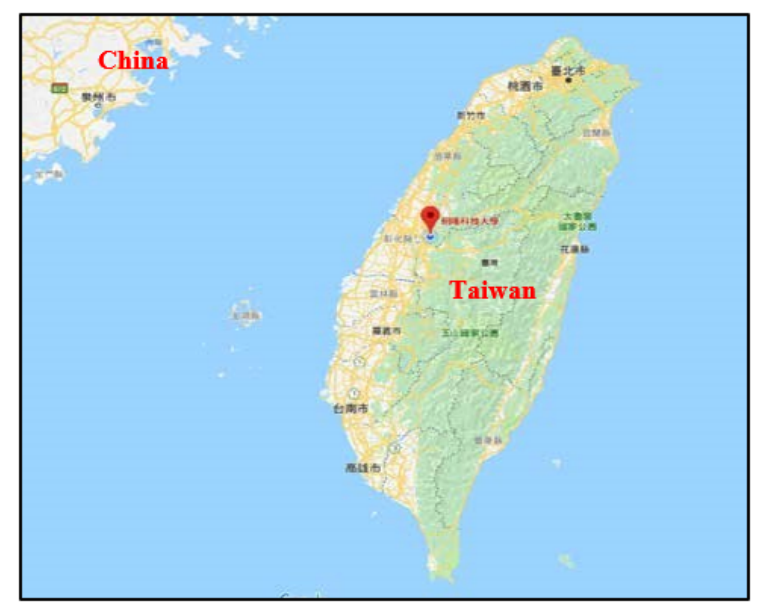

Fig. 1. Location of CYUT.

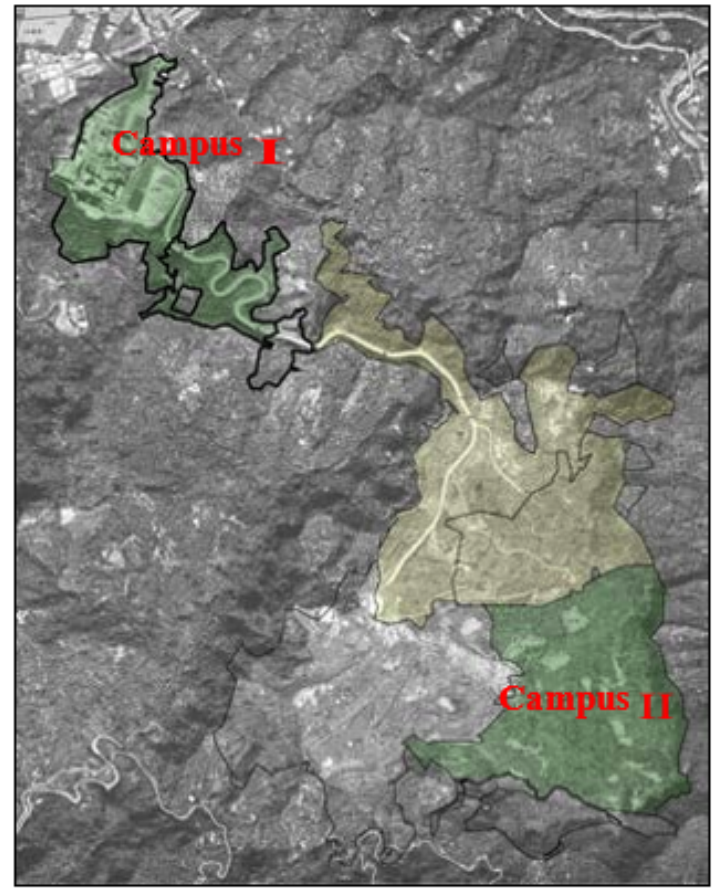

Fig. 2. Campus locations of CYUT.

\section{Factors for green university promotion}

\subsection{Setting up a dedicated organization}

The Office of Environmental Safety and Health of CYUT is the dedicated organization for the promotion of green university. Together with the Office of Academic Affairs, Office of Student Affairs, Office of General Affairs, General Education Center, and other units or departments, the green university promotion committee was formed to act as the principal consultant. Referring to the Sustainable Development Goals set by the United Nations [4] and the environmental characteristics of Taiwan, four different fields of management, including energy and resources, accident prevention and rescue, occupational safety and health, and environmental, have been promoted in the campus of CYUT for this cause. Furthermore, four management practices including implementing management systems, organizing green courses, promoting green activities and creating green environment, have been applied to improve the effectiveness of the campus management (Figure 3). By learning, living and experiencing, the students and staff members can adapt the concept of sustainability in their daily lives and hope to achieve the goal of creating a sustainable and low-carbon campus [5]. 


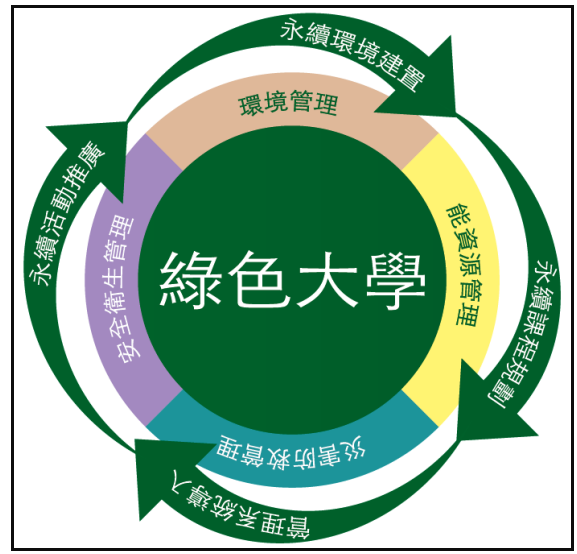

Fig. 3. CYUT's tactics for green university promotion.

\subsection{Participating in green university organizations}

Besides the operation of the in-campus organization, CYUT is aggressively linking other universities and organizations in Taiwan for promoting environmental sustainability. Currently, CYUT is participating in the Green University Union of Taiwan (GUUT) and has partnership with the Central Environmental Education Regional Center and the Environmental Education Facility and Field by the Joint Regional Planning Panel of Chung-Chang-Tou-Miao (Table 1). The main reason for CYUT to join GUUT is for having better connections with other universities in order to promote the works of green university in Taiwan and interact with international green universities academically and practically. On the other hand, having partnership with the Central Environmental Education Regional Center and the Environmental Education Facility and Field by the Joint Regional Planning Panel of Chung-Chang-TouMiao could assist the local government to promote environmental education and raise the public environmental awareness for developing a sustainable society.

Table 1. Environmental sustainability organizations with CYUT participation

\begin{tabular}{lcc}
\hline Name of organization & $\begin{array}{c}\text { Time of } \\
\text { participation }\end{array}$ & \multicolumn{1}{c}{ Remarks } \\
\hline $\begin{array}{l}\text { Green University Union } \\
\text { of Taiwan }\end{array}$ & $\begin{array}{l}\text { 1. Cofounded by CYUT. } \\
\text { 2. The president of } \\
\text { CYUT is one of the } \\
\text { executive directors. }\end{array}$ \\
\hline $\begin{array}{l}\text { Central Environmental } \\
\text { Education Regional }\end{array}$ & 2014.12 \\
Center (Partnership) & & \\
\hline $\begin{array}{l}\text { Environmental } \\
\text { Education Facility and }\end{array}$ & & \\
Field by the Joint \\
$\begin{array}{l}\text { Regional Planning Panel } \\
\text { of Chung-Chang-Tou- }\end{array}$ \\
Miao (Partnership)
\end{tabular}

\subsection{Implementing environmental and energy management systems:}

Since CYUT implemented ISO 14001 Environmental management in 2007, more management systems, such as ISO 14064-1 Greenhouse gases and ISO 50001 Energy management, were implemented in the following years due to the improvement in effectiveness of campus management. By following the PDCA in each system, the energy consumption, environmental risks, and greenhouse gas emissions all could meet the management goals.

Table 2. Environmental and energy management systems implemented in CYUT

\begin{tabular}{cccl}
\hline $\begin{array}{c}\text { Management } \\
\text { systems }\end{array}$ & $\begin{array}{c}\text { Time of } \\
\text { implementation }\end{array}$ & $\begin{array}{c}\text { Time of } \\
\text { certification }\end{array}$ & $\begin{array}{l}\text { Certification } \\
\text { organization }\end{array}$ \\
\hline ISO 14001 & 2007.07 & 2008.01 .14 & $\begin{array}{l}\text { Lloyd's } \\
\text { Inspection } \\
\text { Limited } \\
\text { Taiwan }\end{array}$ \\
\hline $\begin{array}{cccl}\text { ISO 14064- } \\
1\end{array}$ & 2008.06 & 2009.12 .30 & $\begin{array}{l}\text { SGS Taiwan } \\
\text { Ltd }\end{array}$ \\
\hline ISO 50001 & 2010.07 & 2012.03 .22 & $\begin{array}{l}\text { SGS Taiwan } \\
\text { Ltd }\end{array}$ \\
\hline
\end{tabular}

\subsection{Establishing iEN management and monitoring system}

In order to construct smart buildings, CYUT has been establishing management and monitoring systems for water and electricity consumption since 2006. Due to the good results, other management systems including curfew, surveillance, fire, and indoor air quality were added year by year into the system and the combination is called iEN (Intelligent Energy Network) management and monitoring system. The current iEN can function in systems including electricity, water supply and sewerage, air conditioning, lighting, and environment monitoring. The framework and control interface of the iEN system are shown in Figure 4 and Figure 5, respectively.

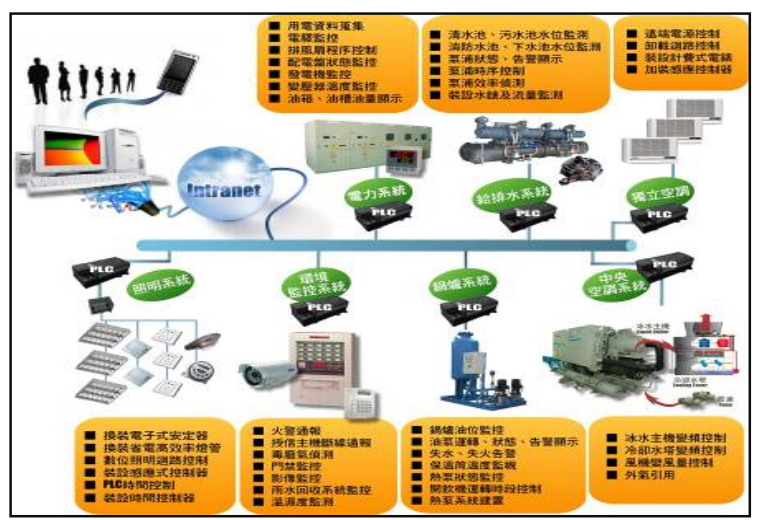

Fig. 4. The framework of the iEN management and monitoring system in CYUT. 




Fig. 5. The control interface of the iEN management and monitoring system in CYUT.

The functions of the iEN management and monitoring system in CYUT are described as follows:

1.Electricity system: including managing the campus demand, collecting and analyzing data from electricity consumption and monitoring relays. Over $95 \%$ of electricity usage in CYUT is controlled by this system.

2.Water supply and sewerage system: including maintenance of water reservoirs in campus (tap water, ground water, waste water and firewater), timing of pumping, recording and monitoring of water usage. The iEN system can control the water pump to function during off-peak periods and it can reduce the electricity consumption during peak hours. Also, by monitoring the water usage, leakage of water pipes can be detected

3.Air conditioning system: functions for central air conditioning system include water cooled chiller and cooling tower with variable frequency drives, and infiltration control; functions for individual air conditioner include remote power control, billing meter and unloading valve circuit operation. Customized air conditioners are purchased with a temperature controlling chip (set at $26^{\circ} \mathrm{C}$ ) built-in. Each classroom follows its own schedule for air conditioning. In other words, only if there is class in the classroom, the air conditioner may function, and vice versa.

4.Lighting system: using time as a factor to switch on/off the outdoor lightings.

5.Environment monitoring system: including curfew, surveillance, fire alarm and detector central control. Also, following the Indoor Air Quality Act of Taiwan, environment monitors, such as carbon dioxide sensors and hygrometer, are placed in the library and in the hall of the Design Building in order to assure air circulation.

\subsection{Building green data centers}

With proper planning in campus spacing, the computer facilities were designed as green data centers. In other words, cold and hot aisles were separated in the facilities. After renovation, the power consumption decreased from $34 \mathrm{kw}$ to $25 \mathrm{kw}$, that is a $26.5 \%$ saving ratio and the power usage effectiveness (PUE) is in the gold level.

\subsection{Replacing old chillers with active magnetic bearing chillers}

Old and less effective water-cooled chillers (720RT) in the library were replaced with new active magnetic bearing chillers (400RT) and the power saving ratio was as high as $51.16 \%$.

\subsection{Replacing power draining lightings}

In order to improve lighting efficiency and reduce power consumption, indoor lightings were all replaced with T5 fluorescent and LED lightings and the power saving ratio was at least $30 \%$. The lightings in the Athletes Building were replaced with electrodeless lamps and the power saving ratio was more than $50 \%$. The lightings in the athletic fields and parking lots were replaced with ceramic discharge metal-halide lamps and the power saving ratio was also more than $50 \%$.

\subsection{Installing green roofs}

According to the data from Taiwan Power Company, the roof of a building is one of the main indoor heat sources since it has the most solar irradiation. Therefore, in order to reduce the heat load and energy consumption of a building, lowering the temperature of the roof is an effective way. Installing green roofs in CYUT not only effectively lowered the indoor temperature but also increased the green open space ratio in campus. Currently, green roofs have been installed on the Design Building, Teaching Building, and Dormitory (Figure 5). From real measurements by the members of the architecture department of CYUT, the indoor temperature could be lowered by more than $2.5^{\circ} \mathrm{C}$ which could save the electricity consumption of air conditioners by more than $15 \%$. Also, CYUT promoted this result to the middle and elementary schools, which are counseling partners of Green University, and helped them install sustainable insulation roofs in order to create low-carbon schools hand in hand.

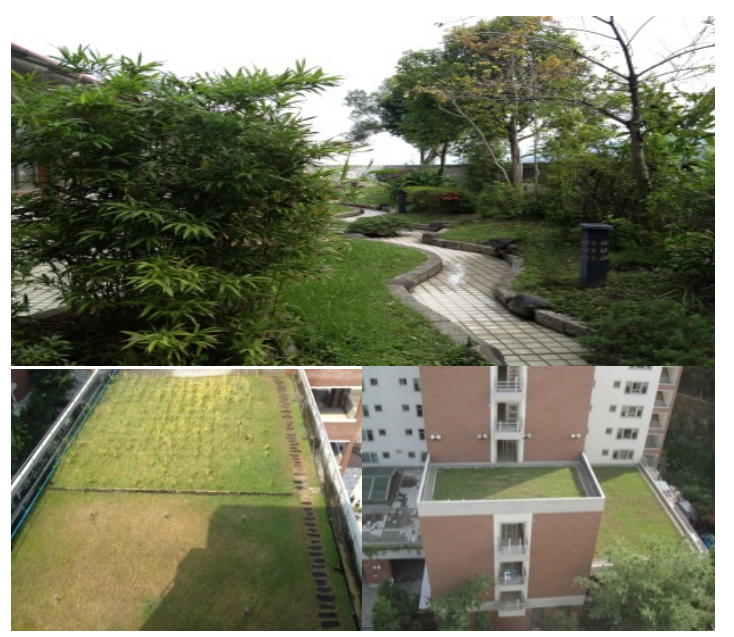

Fig. 6. Green roofs in CYUT

Besides roof installation, vine planting is also aggressively conducted in CYUT since vine plants can 
reduce the heat radiation absorbed by building walls. Currently, vines are planted on the walls of several buildings including Science and Engineering Building, Humanities and Technology Building, Administration Building, Information Building (feature wall), and the retaining walls on the athletic fields (Figure 6).



Fig. 7. Green walls in CYUT

\section{Results}

Due to global warming and the passing of the Sustainable Energy Policy Framework by the Taiwan government, CYUT has been promoting the reduction of greenhouse gas emissions since 2008. After years of striving, the results are fairly good. Using 2008 as the base-year, the electricity consumption decreased from $13,484,000 \mathrm{kwh}$ in 2008 to $10,769,600 \mathrm{kwh}$ in 2017 . The energy use intensity (EUI) also decreased from 85.66 $\mathrm{kwh} / \mathrm{m}^{2}$ to $68.41 \mathrm{kwh} / \mathrm{m}^{2}$ with a reduction ratio of $20.1 \%$ (Table 3). For vehicle and hot water boiler, the oil consumption including gasoline and diesel decreased from 51,093 Liter in 2008 to 46,758 Liter in 2017, and the reduction ratio is $8.5 \%$ (Table 4 ). For greenhouse gas emissions, comparing to the emissions in the base-year of 2008 which is $9,104.82$ metric tonnes $\mathrm{CO} 2 \mathrm{e}$, the emissions in 2017 was lowered to 6,268.41 metric tonnes $\mathrm{CO} 2 \mathrm{e}$ which is a decrement of $2,836.41$ metric tonnes $\mathrm{CO} 2 \mathrm{e}$ and the reduction ratio is $31.2 \%$ (Table 5).

Table 3. Electricity consumption in CYUT.

\begin{tabular}{ccc}
\hline Year & Electricity Used(kwh) & EUI $\left(\mathrm{kwh} / \mathrm{m}^{2}\right)$ \\
\hline 2008 & $13,484,000$ & 85.66 \\
\hline 2009 & $13,782,800$ & 87.55 \\
\hline 2010 & $13,485,200$ & 85.66 \\
\hline 2011 & $13,229,600$ & 84.04 \\
\hline 2012 & $12,518,600$ & 79.52 \\
\hline 2013 & $12,106,200$ & 76.90 \\
\hline 2014 & $11,860,400$ & 75.34 \\
\hline 2015 & $12,107,200$ & 76.91 \\
\hline 2016 & $11,653,600$ & 74.03 \\
\hline
\end{tabular}

Table 4. Oil consumption in CYUT

\begin{tabular}{cccc}
\hline \multirow{2}{*}{ Year } & \multicolumn{2}{c}{ Vehicle } & Hot water boiler \\
\cline { 2 - 4 } & $\begin{array}{c}\text { Gasoline } \\
\text { (Liter) }\end{array}$ & Diesel(Liter) & Diesel (Liter) \\
\hline 2008 & 25,951 & 1,294 & 23,848 \\
\hline 2009 & 22,615 & 4,968 & 21,463 \\
\hline 2010 & 23,646 & 4,317 & 21,781 \\
\hline 2011 & 21,543 & 9,263 & 29,600 \\
\hline 2012 & 12,738 & 11,359 & 29,800 \\
\hline 2013 & 17,998 & 11,193 & 26,000 \\
\hline 2014 & 18,652 & 11,176 & 29,200 \\
\hline 2015 & 17,539 & 10,529 & 32,600 \\
\hline 2016 & 17,210 & 9,562 & 27,800 \\
\hline 2017 & 16,034 & 10,524 & 20,200 \\
\hline
\end{tabular}

Table 5. Greenhouse gas emissions in CYUT

\begin{tabular}{cccc}
\hline Year & $\begin{array}{c}\text { Emissions (metric } \\
\left.\text { tonnes } \mathrm{CO}_{2} \mathrm{e}\right)\end{array}$ & $\begin{array}{c}\text { Reduction } \\
\text { from base- } \\
\text { year }\end{array}$ & Remarks \\
\hline 2008 & $9,104.82$ & -- & base-year \\
\hline 2009 & $9,173.48$ & -68.66 & \\
\hline 2010 & $8,855.43$ & 249.39 & \\
\hline 2011 & $7,707.68$ & $1,397.14$ & \\
\hline 2012 & $7,449.75$ & $1,655.07$ & \\
\hline 2013 & $6,991.79$ & $2,113.03$ & \\
\hline 2014 & $6,897.23$ & $2,207.59$ & \\
\hline 2015 & $7,018.10$ & $2,086.72$ & \\
\hline 2016 & $6,775.35$ & $2,329.47$ & \\
\hline 2017 & $6,268.41$ & $2,836.41$ & \\
\hline Total reduction $($ metric & $14,806.16$ & \\
tonnes $\left.\mathrm{CO}_{2} \mathrm{e}\right)$ &
\end{tabular}

\section{Conclusion}

According to the assessment reports by IPCC, it is getting more obvious that global warming and climate change are caused by massive usage of fossil fuel by humans and the consequences are huge loss of lives and properties. It is inevitable to reduce the use of fossil fuel and improve the efficiency of energy utilization. Since the operational logic behind campus life is a kind of pseudo-socialization process [6], universities should also take responsibility for leading people to face the challenge from climate change.

For creating a green campus in CYUT, the management goals for energy consumption and greenhouse gas emissions have been achieved in recent years by implementing energy management systems, replacing high energy consuming facilities, installing green roofs, and changing the behaviors of students and staffs. For improving in the future, ISO 14001 Environmental management and ISO 50001 Energy management will still be implemented to reduce the energy consumption and increase the efficiency of energy utilization. Last but not least, environmental education will be emphasized to raise the environmental awareness of the students and staffs for creating a lowcarbon and sustainable campus in CYUT. 


\section{References}

1. Intergovermental Panel on Climate Change (IPCC), Available online at http://www.ipcc.ch/

2. Huang-Hsiung Hsu, Chia Chou, Yi-Chao $\mathrm{Wu}$, Mong-Ming Lu, Cheng-Ta Chen, Yung-Ming Chen, Climate Change in Taiwan: Scientific Report 2011(Summary), National Science Council, Taipei, Taiwan, ROC (2011)

3. Executive Yuan Agriculture Bureau Forestry, Available online at http://lifetree.forest.gov.tw/cp05.asp
4. United Nations, Available online at http://www.un.org/sustainabledevelopment/sustaina ble-development-goals/

5. Chaoyang University of Technology Officer for Environmental Safety and Health, "2017 Campus Environment Report" (unpublished), Chaoyang University of Technology, (2018)

6. Cortese, A, The Critical Role of Higher Education in Creating a Sustainable Future, Planning for Higher Education. March-May 2003: pp.15-22, (2003) 